\title{
SOSIALISASI PEMBUATAN SOAL MELALUI GOOGLE FORM DALAM MENINGKATKAN KOMPETENSI GURU PAI
}

\author{
Mahyudin Ritonga ${ }^{1}$, Ahmad Lahmi ${ }^{2}$, Rimelfi ${ }^{3}$, Fathul Bahri ${ }^{4}$, \\ Ilyas Tuangku Bagindo 5 \\ 1,2,5Universitas Muhammadiyah Sumatera Barat, Indonesia \\ ${ }^{3}$ Guru Pendidikan Agama Islam SMA Negeri 1 Padang, Indonesia \\ ${ }^{4}$ Guru Pendidikan Agama Islam SMK 2 Pariaman, Indonesia \\ 1mahyudinritonga@gmail.com
}

\begin{abstract}
The emergence of cases pandemic Covid-19 in China and various other countries to be a concern for AGPAII (Association of Islamic Religious Education teachers) in West Sumatera region will appear in the end of the 2nd Semester 2019/2020 school year in Indonesia without exception in West Sumatera, so it is difficult for teachers to conduct a final exam. Predictions from the AGPAII caretaker took place since March 2020 PSBB began to be enforced in West Sumatera and every education institution in the group. This activity is carried out in the form of socialization and training, the target that is to be achieved in this activity is the realization of PAI teacher skills utilizing Google form in conducting evaluation. The parties involved in this activity are AGPAII administrators as organizers and speakers, the expert team as the main speaker of the University of Muhammadiyah West Sumatera, PAI teacher who joined in AGPAII as an object. The result of this activity is the participant who participated in training activities as many as 142 people, the speaker socialize with the method of lecture and provide training through the simulation, participants can make questions through the Google form.
\end{abstract}

Keywords: Covid-19, Google form, teacher competence, socialization

\begin{abstract}
Abstrak
Munculnya kasus pandemic covid-19 di China dan berbagai negara lain menjadi kekhawatiran bagi pengurus AGPAII (Asosiasi Guru Pendidikan Agama Islam Indonesia) Wilayah Sumatera Barat akan munculnya kasus tersebut pada akhir semester 2 tahun ajaran 2019/2020 di Indonesia tanpa terkecuali di Sumatera Barat, sehingga menyulitkan guru dalam mengadakan ujian akhir. Prediksi dari pengurus AGPAII benar terjadi sejak Maret 2020 PSBB mulai diberlakukan di Sumatera Barat dan setiap lembaga pendidikan di liburkan. Kegiatan ini dilaksanakan dalam bentuk sosialisasi dan pelatihan, target yang ingin dicapai dalam kegiatan ini ialah terwujudnya keterampilan guru PAI memanfaatkan google form dalam melaksanakan evaluasi. Pihak-pihak yang terlibat dalam kegiatan ini ialah pengurus AGPAII sebagai panitia dan narasumber, team ahli sebagai narasumber utama dari Universitas Muhammadiyah Sumatera Barat, guru PAI yang tergabung dalam AGPAII sebagai objek. Hasil kegiatan ini ialah peserta yang mengikuti kegiatan pelatihan sebanyak 142 orang, narasumber melakukan sosialisasi dengan metode ceramah dan memberikan pelatihan melalui simulasi, peserta dapat membuat soal melalui google form.
\end{abstract}

Kata Kunci: covid-19, google form, kompetensi guru, sosialisasi

\begin{tabular}{l|l|l} 
Submitted: 2020-09-06 & Revised: 2020-09-14 & Accepted: 2020-09-16
\end{tabular}

\section{Pendahuluan}

Virus Covid-19 sebagaimana diketahui pertama kali muncul di China dan secara pesat menyebar ke berbagai negara tanpa terkecuali negara Indonesia. Munculnya 
pandemic covid-19 berpengaruh besar terhadap berbagai aspek kehidupan manusia, seperti ekonomi, kehidupan sosial, aktivitas dan sistem pendidikan.

Pernyataan ini didasarkan pada kesimpulan Ozili yang mengungkapkan bahwa krisis kesehatan dunia sebagaimana pada covid-19 mempengaruhi perekonomian global (Ozili \& Arun, 2020), bahkan imbas dari covid-19 lebih besar tehadap permasalahan ekonomi dibanding permasalahan kesehatan itu sendiri. Mckibbin dan Fernando juga mengutarakan bahwa permasalahan virus Covid-19 sudah banyak pengusaha yang tidak berani untuk berinfestasi karena menyimpan sendiri lebih aman dibanding mengharapkan keuntungan dari kekayaan yang ada saat ini (Mckibbin \& Fernando, 2020).

Dalam kehidupan sosial, pengaruh yang begitu terasa adalah terputusnya komunikasi langsung antar anggota masyarakat akibat dari pemberlakuan kebijakan lockdown dan pembatasan sosial berskala besar (PSBB). Singh dan Singh menegaskan bahwa virus corona benar-benar merubah pola kehidupan bermasyarakat (Singh \& Singh, 2020).

Selain masalah ekonomi dan kehidupan sosial, dampak yang paling terasa dari munculnya virus corona ialah terhadap dunia pendidikan, dimana sistem pembelajaran harus beralih dari sistem tatap muka kepada sistem daring (Aji, 2020) dengan memanfaatkan berbagai aplikasi berupa zoom cloud meetings (Almarzooq et al., 2020), google calssroom, edmodo, ruang guru maupun sistem yang disediakan sendiri oleh lembaga pendidikan.

Berbagai dampak tersebut di atas sebenarnya belum sampai di Indonesia dan Sumatera Barat secara khusus pada saat munculnya ide pelaksanaan kegiatan ini. Namun pada posisi inilah dapat diberikan apresiasi kepada pengurus Asosiasi Guru Pendidikan Agama Islam indonesia (AGPAII) Wilayah Sumatera Barat, dengan melihat dampak Covid19 pada beberapa negara terutama China, Italia dan Amerika pada saat itu, pengurus AGPAII meyakini dampak yang sama akan sampai ke negara Republik Indonesia yang dalam prediksi mereka dampak itu akan terasa di Indonesia pada akhir semester genap 2019/2020.

Prediksi dari pengurus AGPAII itu ternyata benar bahkan jauh lebih cepat dari yang mereka perkirakan, dimana Sumatera Barat pada akhir Maret 2020 melalui dinas pendidikan mengantisipasi penularan virus corona sehingga sekolah dan perguruan tinggi pun menyelenggarakan pembelajaran dan perkuliahan secara daring. Apresiasi yang diberikan kepada AGPAII ialah dari cara berpikir yang jauh ke depan, prediksi terhadap akan sampainya penularan virus corona ke Sumatera Barat ternyata sudah mereka pikirkan berbagai kendala yang akan dihadapi oleh guru PAI dalam mensukseskan proses pembelajaran, karena prediksi akan sampainya ke Indonesia pada akhir semester maka mereka memikirkan bagaimana kelangsungan pendidikan jika hal itu terjadi tepat pada saat pelaksanaan ujian naik kelas.

Sesuai dengan kemampuan guru PAI dalam memanfaatkan teknologi pada saat pembelajaran maka gagasan yang muncul dari sebagian pengurus AGPAII di daerah ialah memberikan pelatihan penggunaan google form dalam pembuatan soal ujian. Sebelum memutuskan bentuk pelatihan apa yang akan diberikan kepada guru-guru, sebagaimana diungkapkan Bahri terlebih dahulu dia melakukan survey melalui group whatsApp kepada guru-guru yang tergabung dalam organisasi profesi AGPAII Daerah Padang Pariaman, beberapa alternatif yang ditawarkan adalah pelatihan PTK, pelatihan penyusunan LKS, 
pelatihan pembuatan media, namun dari sekian banyak opsi yang ditawarkan tingkat keterpilihan untuk pelatihan pembuatan soal dengan menggunakan google form sangat tinggi.

Sejalan dengan itu, pengurus AGPAII Pariaman melalui ketua Wilayah AGPAII Sumatera Barat melakukan koordinasi kepada Universitas Muhammadiyah Sumatera Barat tentang ketersediaan Sumber Daya Manusia untuk memberikan pelatihan dimaksud, karena jauh sebelum diadakannya pelatihan ini kerjasama dalam bidang pendidikan dan pengajaran serta penelitian dan pengabdian masyarakat telah terjalin antara AGPAII dan Program Pascasarjana Universitas Muhammadiyah Sumatera Barat, dan salah satu bentuk realisasi dari MOU ini adalah pengabdian masyarakat.

Ketersediaan SDM di PPs Universitas Muhammadiyah Sumatera Barat untuk memberikan pelatihan ini kemudian pihak AGPAII daerah Pariaman menyusun TOR guna kelangsungan kegiatan pelatihan pembuatan soal melalui google form.

Sosialisasi dan pelatihan ini bertujuan untuk meningkatkan kompetensi guru Pendidikan Agama Islam dalam memanfaatkan teknologi untuk bidang pendidikan, karena realita yang tidak dapat dipungkiri adalah banyak di antara guru yang belum mampu untuk memanfaatkan teknologi dalam pembelajaran, pelatihan ini urgen bagi guru apalagi dalam kaitan kompetensi guru pada masa covid-19. Adapun tujuan secara khusus dari kegiatan ini ialah: 1) Guru PAI mengetahui secara komprehensif tentang google form, 2) Guru PAI dapat menggunakan google form dalam melaksanakan evaluasi PAI.

\section{Metode}

Untuk mewujudkan tujuan yang dijelaskan di atas, pengabdian ini dilaksanakan dengan metode "Pelatihan". Maksudnya adalah narasumber terlebih dahulu melakukan sosialisasi tentang google form yang kemudian dilanjutkan dengan mendemonstrasikan serta mencontohkan bagaimana pembuatan google form dalam rangka evaluasi pendidikan.

Adapun tempat pelaksanaan ini ialah di Bertempat di Balairung Rumah Dinas Walikota Pariaman sesuai dengan denah pada photo google mapp berikut ini:

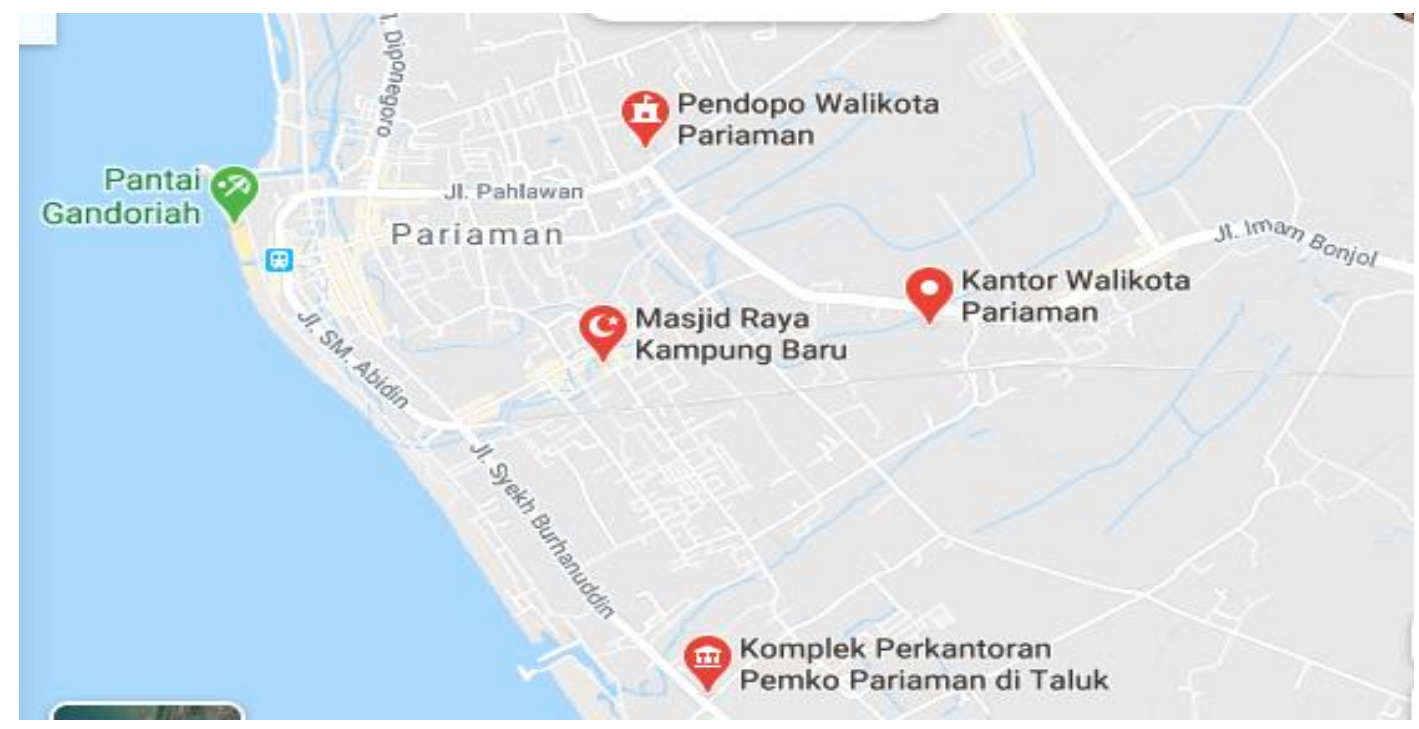

Gambar 1. Tempat Pelatihan 
Sementara peserta kegiatan sosialisasi dan pelatihan ini ialah sebanyak 142 (Seratus Empat Puluh Dua) orang guru yang tergabung dalam organisasi AGPAII Kota Pariaman sesuai daftar hadir yang ada. Sementara pihak yang terlibat dalam kegiatan ini adalah 2 (dua) orang narasumber ahli, 1 (satu) orang narasumber dari AGPAII dan panitia pelaksana. Kegiatan ini secara resmi juga dibuka oleh WaliKota Pariaman Dr. Genius Umar, M.Si dan Kata sambutan dari Kepala Dinas dan Kemenag Kota Pariaman. Waktu pelaksanaan kegiatan ini tepatnya pada Hari Jumat 13 Maret 2020.

\section{Hasil dan Pembahasan}

\section{Deskripsi Kegiatan}

Sesuai dengan scedhul kegiatan sosialisasi yang telah disusun oleh panitia, dapat dideskripsikan bahwa kegiatan ini diawali dengan pembacaan ayat suci al-Qur'an kemudian dilanjutkan dengan lagu Indonesia Raya dan Mars AGPAII. Setelah itu kata sambutan dari pengurus AGPAII, kepala kantor dinas pendidikan Kota Pariaman, kata sambutan dari kepala kantor kementerian agama Kota Pariaman dan pembukaan acara pelatihan secara resmi oleh Walikota Pariaman. Pembukaan acara ini dapat dilihat sebagaimana pada gambar 2 di bawah ini:

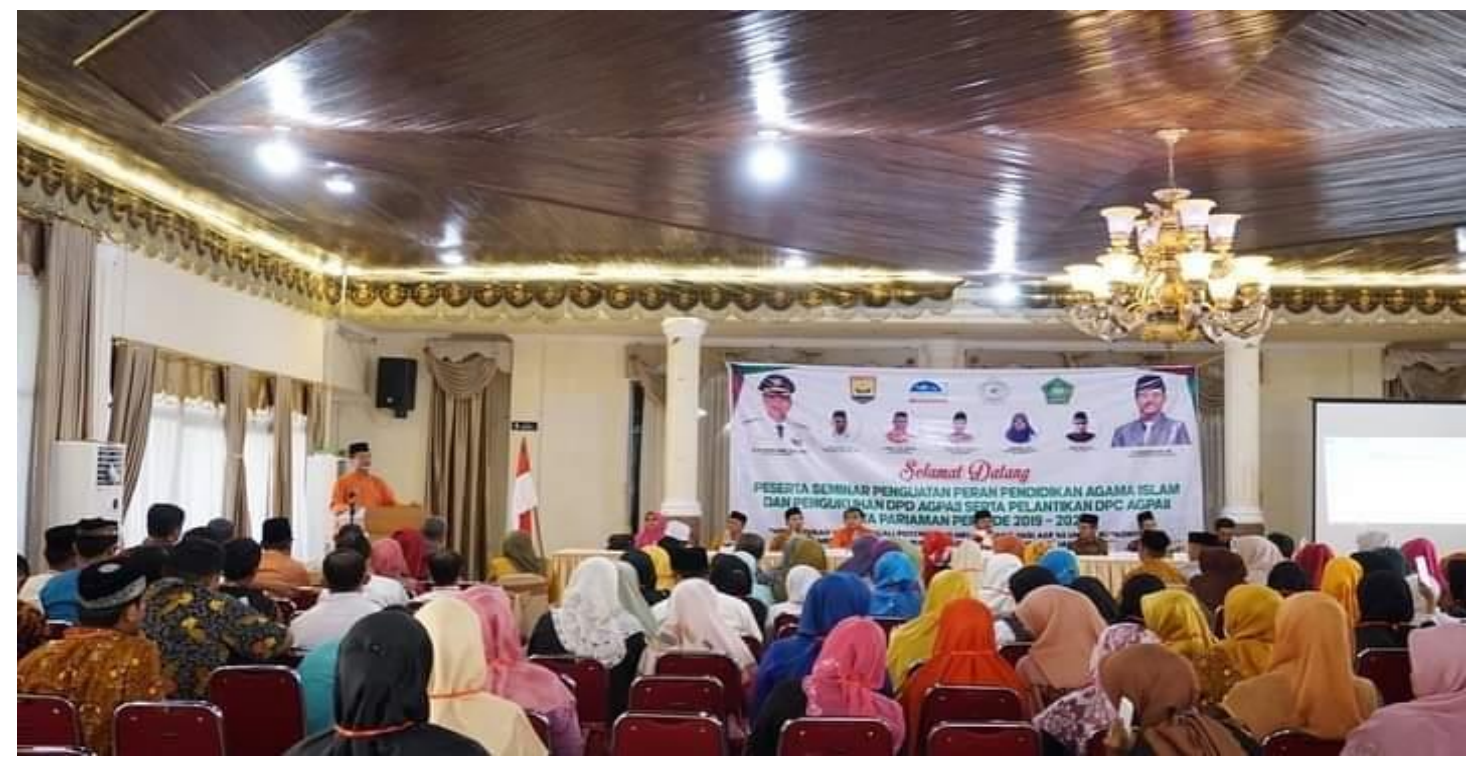

Gambar 2. Pembukaan acara pelatihan oleh Walikota Pariaman

Dalam sambutannya Walikota menegaskan bahwa guru pendidikan agama Islam merupakan garda terdepan dalam melakukan pembinaan akhlak dan karakter anak bangsa, oleh karenanya kemampuan siswa dalam menggunakan berbagai alat teknologi jangan sampai mengarah pada hal-hal yang negatif yang dapat merusak pola pikir dan prilaku mereka.

Untuk itu, guru pendidikan agama Islam harus mampu memberikan edukasi pemanfaatan teknologi dalam dunia pendidikan, dan bagaimana teknologi dijadikan sebagai media untuk meningkatkan kualitas siswa dan meraih kesuksesan belajar melalui pemanfaatan teknologi. Oleh karenanya, pelatihan penggunaan google form diharapkan dapat meningkatkan kemampuan guru PAI dalam memanfaatkan teknologi. 
Selain itu, Walikota juga menambahkan bahwa pemerintah kota Pariaman akan selalu memberikan support terhadap setiap program AGPAII yang outputnya dapat diukur serta manfaatnya dapat dirasakan masyarakat, sebagai contoh realnya pemerintah Kota Pariaman akan menjadikan masjid terapung yang sedang dibangun sebagai labor PAI di Kota Pariaman.

\section{Hasil Pelatihan}

Hasil pelaksanaan pengabdian ini dapat digambarkan mulai dari penyampaian materi oleh narasumber, demonstrasi dan pemberian contoh.

Pertama, penyampaian materi, materi yang disampaikan oleh kedua narasumber utama dalam pengabdian ini ialah terkait penggunaan tools. Materi yang disampaikan terkait dengan topik ini ialah meliputi pengertian, fungsi, keunggulan, dan cara membuat google form. Penyampaian materi ini dapat dilihat seperti dalam gambar 3 berikut:

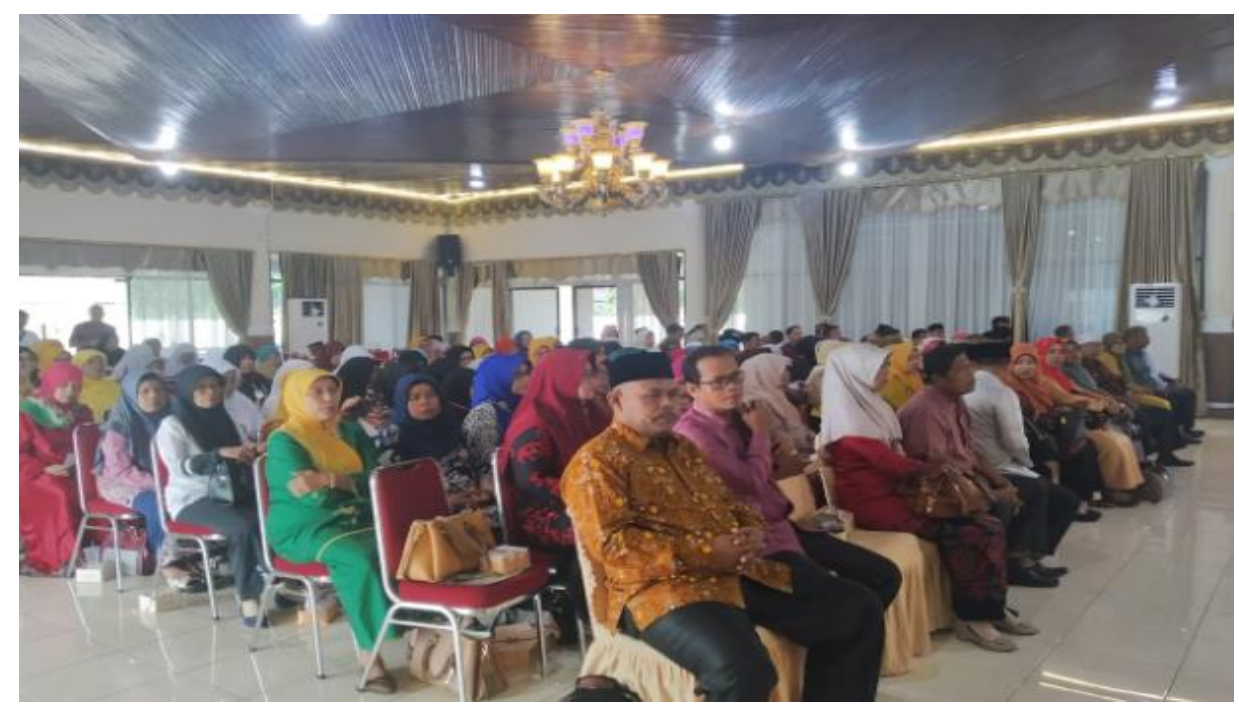

Gambar 3. Peserta Pelatihan mendengarkan Penyampaian Materi

Berdasarkan pemaparan narasumber google form dapat digunakan dalam berbagai aspek kehidupan dan memudahkan bagi pengguna dalam melakukan rekapitulasi data. Terkait dengan pengertian google form sebagaimana disampaikan oleh narasumber bahwa google form merupakan pemanfaatan google untuk mengumpulkan data sesuai dengan yang diinginkan administrator. Dalam kaitan pelatihan ini guru berfungsi sebagai administrator yang ingin mengumpulkan data tentang hasil belajar PAI.

Sementara fungsi google form dalam melaksanakan evaluasi pembelajaran sesuai yang disampaikan oleh narasumber ialah sebagai ganti lembaran soal yang dapat digunakan guru untuk memuat kisi-kisi soal langsung dengan alternatif jawaban yang dapat dikerjakan siswa secara langsung dan guru bisa mengatahui secara cepat rekapitulasi jawaban yang benar dan salah, sehingga skor dan nilai dari masing-masing siswa dapat diketahui secara cepat.

Menurut narasumber, pemanfaatan googel form dalam evaluasi pembelajaran sangat membantu baik secara ekonomis maupun moril, dikatakan membantu secara ekonomis ialah karena tidak membutuhkan kertas dan alat tulis, sementara secara moril 
guru cukup menyediakan form, membuat instruksi dan menyebarkannya kepada peserta didik, setelah itu guru bisa melakukan aktivitas lain sambil menungggu isian dari semua siswa.

Namun menurutnya, pendidikan agama Islam sebagai mata pelajaran yang berorientasi pada pembentukan akhlak dan karakter peserta didik, pemanfaatan google form sebagai media evaluasi memiliki banyak kekurangan, karena membuka peluang bagi siswa untuk meminta bantuan kepada orang-orang di sekelilingnya guna menjawab soal. Selain itu, pendidikan agama Islam yang porsi penilaiannya juga mempertimbangkan prilaku nyata dari masing-masing siswa cenderung tidak tercover.

Adapun strategi pembuatan google form untuk evaluasi pembelajaran PAI sebagaimana yang disampaikan oleh narasumber ialah: 1) setiap guru PAI haru memiliki google drive terlebih dahulu, setelah itu 2) guru membuat nama template sesuai yang dibutuhkan kemudian mengisinya sesuai dengan berapa jumlah kisi-kisi soal yang diinginkan dan membuat langsung alternatif jawaban.

Setelah penyampaian materi pelatihan yang secara langsung didemonstrasikan peserta pelatihan diminta untuk mempraktekkan pembuatan google form untuk evaluasi PAI, hasil google form yang dibuat oleh guru-guru PAI tersebut kemudian diminta untuk dikirimkan ke WA salah seorang narasumber sebagai bentuk evaluasi, dari 142 (seratus empat puluh dua) orang yang mengikuti pelatihan terdapat 131 (seratus tiga puluh satu) google form yang dikirim ke WA narasumber, hasil ini terlihat sebagaimana pada tabel 1 berikut ini:

Tabel 1. Hasil Pembuatan google form

\begin{tabular}{ccc}
\hline Peserta & Peserta yang mengirim & Peserta yang tidak mengirim \\
\hline 142 & 131 & 11 \\
\hline
\end{tabular}

Dari tabel 1 di atas dapat dikatakan bahwa pelaksanaan pelatihan pembuatan google form untuk guru-guru yang tergabung dalam AGPAII Wilayah Sumatera Barat Daerah Kota Pariaman dapat dikatakan berhasil, karena hanya 11 (sebelas) orang yang tidak membuat dan tidak mengirimkan google form yang dihasilkannya kepada narasumber.

Salah satu contoh google form yang dibuat oleh peserta pelatihan ialah dapat dilihat sebagaimana pada gambar 4 di bawah ini:

SOAL PAI KELAS V SD NEGERI 12 PARIAMAN

Kitab Suci umat Islam adalah
al-Quran
Taurat
Injil
Zabur

Gambar 4. Contoh Google form oleh Salah Seorang Peserta Pelatihan 
Dari hasil yang dipaparkan di atas dapat dikatakan bahwa pelatihan google form dapat meningkatkan kompetensi guru PAI di Kota Pariaman. Dalam hal ini peningkatan kompetensi itu terlihat dalam kompetensi profesional, guru memiliki kemampuan memanfaatkan teknologi dalam menjalankan tugasnya sebagai tenaga profesional.

Hasil pelatihan ini sesuai dengan hasil pengabdian yang dilakukan oleh Batubara dan Ariani yang menyimpulkan bahwa peserta pelatihan memahami secara benar penggunaan google form sebagai media untuk melakukan evaluasi pembelajaran (Batubara \& Ariani, 2016) . kesimpulan yang tidak jauh berbeda juga disampaikan oleh Mardiana dan Purwanto yang mengatakan bahwa guru menilai bahwa google form dapat dijadikan sebagai alternatif dalam melakukan evaluasi pembelajaran (Mardiana \& Purwanto, 2017).

Mencari alternatif dari permasalahan yang terjadi dalam dunia pendidikan adalah merupakan bentuk inovasi guru dalam posisinya sebagai inovator (Hariyadi et al., 2019). Inovasi yang dapat dilakukan guru dalam suasana Covid-19 ialah penggunaan dan pemanfaatan teknologi dalam pembelajaran, Reimers dkk serta Livari dkk menegaskan bahwa untuk kelangsungan pendidikan pada masa pandemic covid-19 ialah dengan memanfaatkan teknologi pada berbagai aktivitas pembelajaran (Reimers et al., 2020), (Iivari et al., 2020).

Sosialisasi dan pelatihan pembuatan instrumen evaluasi PAI kepada guru-guru yang tergabung dalam AGPAII sebagaimana dalam pengabdian ini memberikan dampak terhadap guru terutama dalam memanfaatkan teknologi untuk melaksanakan evaluasi PAI. Hasil pengabdian ini berbeda dengan kesimpulan Park dan Kim yang menyimpulkan adanya perbedaan gender dalam merespon google form (Kim \& Park, 2012).

Perbedaan itu terlihat pada beberapa aspek, Kim \& Park melakukan uji responden terhadap penggunaan google class room, sementara pengabdian ini memperlihatkan kemampuan membuat google form tidak terlihat antara laki-laki dan perempuan, karena 131 orang yang menyiapkan google form terdapat keseimbangan antar kedua jenis kelamin tersebut sesuai daftar hadir yang ada, begitu juga dengan 11 orang yang tidak mengirimkan google form hasil karyanya terdapat laki-laki dan perempuan.

\section{Kesimpulan}

Dari pemaparan hasil dan pembahasan terhadap hasil pelaksanaan sosialisasi dan pelatihan dapat disimpulkan bahwa kompetensi guru PAI yang tergabung dalam organisasi profesi AGPAII meningkat setelah diadakannya pelatihan pembuatan soal dengan menggunakan google form. Kemampuan ini dapat diaktualisasikan pada masa pandemic Covid-19 dalam memberikan latihan dan evaluasi pembelajaran secara daring. Pengabdian selanjutnya dapat dikembangkan dalam bentuk sosialisasi maupun pelatihan lain pada bidang teknologi pendidikan agar kebermanfaatan teknologi dalam ranah pendidikan semakin dirasakan oleh semua praktisi bidang pendidikan.

\section{Daftar Pustaka}

Aji, R. H. S. (2020). Dampak Covid-19 pada Pendidikan di Indonesia: Sekolah, Keterampilan, dan Proses Pembelajaran. SALAM: Jurnal Sosial \& Budaya Syar'i, $7(5)$, 
395-402. https://doi.org/10.15408/sjsbs.v7i5.15314

Almarzooq, Z., Lopes, M., \& Kochar, A. (2020). Virtual Learning during the COVID-19 Pandemic: A Disruptive Technology in Graduate Medical Education. Journal of the American College of Cardiology, April. https://doi.org/10.1016/j.jacc.2020.04.015

Batubara, H. H., \& Ariani, D. N. (2016). Workshop Penggunaan Google Form sebagai Media Evaluasi Pembelajaran pada Dosen-Dosen Fakultas Studi Islam. Jurnal A/Ikhlas, 2(1), 39-44.

Hariyadi, Ritonga, M., \& Irfadila, M. S. (2019). Pemanfaatan Media TI pada SDN 26 Pulakek Kab. Solok Selatan untuk Meningkatkan Mutu dan Inovasi Pembelajaran. Jurnal Pengabdian Untuk Mu NegeRI, 3(2), 85-88.

Iivari, N., Sharma, S., \& Ventä-olkkonen, L. (2020). Digital transformation of everyday life - How COVID-19 pandemic transformed the basic education of the young generation and why information management research should care? International Journal of Information Management, June, 102183. https://doi.org/10.1016/j.ijinfomgt.2020.102183

Kim, D. D. K., \& Park, C. (2012). Gender Differences in the Effectiveness of Google Forms in Class. Journal of Instructional Pedagogies, JFebruari), 1-9.

Mardiana, T., \& Purwanto, A. W. (2017). Google Form Sebagai Alternatif Pembuatan Latihan Soal Evaluasi. The 6th University Research Colloqium 2017 Universitas Muhammadiyah Magelang, 183-188.

Mckibbin, W., \& Fernando, R. (2020). Economics in the Time of COVID-19 (Issue May). CEPR Press.

Ozili, P., \& Arun, T. (2020). Spillover of COVID-19: Impact on the Global Economy. JEL Classification, 21(March), 1-27. https://doi.org/10.2139/ssrn.3562570

Reimers, F., Schleicher, A., Saavedra, J., \& Tuominen, S. (2020). An annotated selection of online resources supporting education continuity during the COVID-19 Pandemic. Golbal Education Innovation Initiative, 1-38.

Singh, J., \& Singh, J. (2020). Covid-19 and its Impact in Society. Electronic Research Journal of Social Sciences and Humanities, 2(I), 168-172. 